\title{
Ceramic petrography, mineralogy and typology of Eneolithic pottery from Krašnja, Slovenia
}

\author{
Andreja Žibrat Gašparič ${ }^{1}$, Milena Horvat ${ }^{1}$ and Breda Mirtič ${ }^{2}$ \\ 1 University of Ljubljana, Faculty of Arts, Department of Archaeology, SI \\ andreja.zibrat.gasparic@gmail.com \\ 2 University of Ljubljana, Faculty of Natural Sciences and Engineering, Department of Geology, SI
}

\begin{abstract}
In this article, we present newly excavated Eneolithic pottery from the site at Krašnja near Lukovica in central Slovenia. The material was AMS ${ }^{14} \mathrm{C}$ dated and is contemporaneous with archaeological sites from the Ljubljansko barje region in Slovenia. The vessels were reconstructed and then various types of pots, dishes, cups, and beakers were analysed using petrography and the X-ray diffraction method. Additionally, the clay remains of walls and the floor of an Eneolithic kiln excavated at the site were also analysed. The results show that Eneolithic potters used different fabrics to make vessels, and mostly one recipe with added calcite. The raw source material probably came from a nearby valley to the south of the site at Krašnja.
\end{abstract}

IZVLEČEK - V članku predstavljamo eneolitsko lončenino z novoodkritega najdičča Krašnja pri Lukovici v osrednji Sloveniji. Najdišče je bilo AMS ${ }^{14} \mathrm{C}$ datirano in je sočasno z najdišči iz območja Ljubljanskega barja. Lončenino smo lahko rekonstruirali v različne tipe posod, med drugim lonce, sklede, skodelice in čaše, ki smo jih nato preiskali še s petrografsko metodo in metodo rentgenske difrakcije. Dodatno smo preiskali tudi sledove glinenih oblog stene in tal ene od dveh eneolitskih peči, ki smo jih odkrili na najdišču. Rezultati kažejo, da so lončarji v obdobju eneolitika uporabljali različne glinene mase za pripravo posod, vendar predvsem en lončarski recept $z$ dodanim zdrobljenim kalcitom. Naravno surovino, glino, so morda nabirali v sosednji dolini, ki se nahaja južno od najdišča Krašnja.

KEY WORDS - Eneolithic; pottery; typology; petrography; microfossils

\section{Introduction}

The mineralogical properties of pottery and clay play an important part in pottery analysis and are helpful in understanding past technologies. Nevertheless, the mineralogical composition of ceramic objects can be significantly altered by production techniques, from the cleaning of clays, addition of temper, forming of objects, firing conditions and atmosphere. The life cycle of pottery and its use as well as post-depositional changes are also important and can contribute to altering the mineralogical composition. Through this whole operational sequence of pottery, we try to reconstruct past technologies and production techniques (Sillar, Tite 2000; Whitbread 1995).
In this article, we present recent analyses of pottery from the new site at Krašnja in central Slovenia, which was excavated in 2013 during the reconstruction of the gas pipeline M2/1 Trojane-Vodice. The excavated material dates from the Eneolithic and the Bronze Age period to the Medieval Ages and the Industrial period. We focus here on the Eneolithic material excavated, as well as on the remains of two kilns preserved in situ. The pottery assemblage is not large, but is nevertheless comprised of various types of pots, dishes, bowls, cups and beakers. The various types of vessels as well as the remains of a ceramic kiln were chosen for mineralogical analyses using petrography and X-ray diffraction techniques. 


\section{Krašnja near Lukovica}

Krašnja is a village near Lukovica in central Slovenia located in the lower part of the Črni graben valley, north of the Radomlja River. To the south, it is bordered by the steep slopes of the Limbarska gora and Golčaj hills, and to the north by the mountain ridges of Jagodnik, Kotle and Cicelj. Many small streams flow from this direction, commonly flooding this area. The valley and surrounding hills are composed mostly of dark grey to

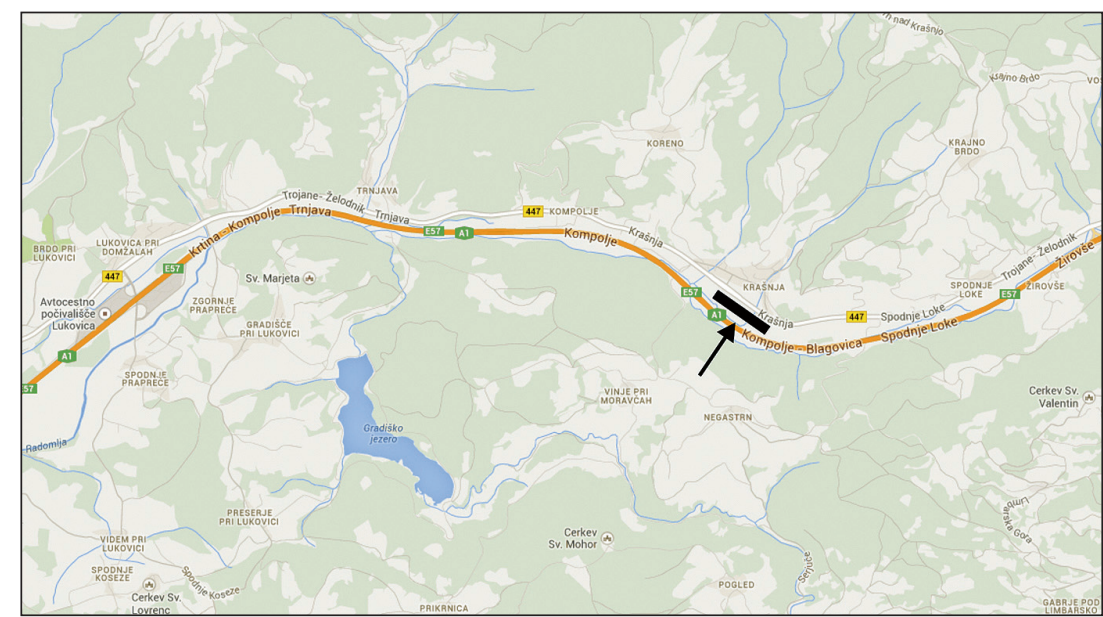

Fig. 1. The geographical position of Krašnja near Lukovica in the Črni graben valley in central Slovenia. black Palaeozoic siltstones and fine-grained sandstones. The archaeological site is located south of the local road and north of the A1 motorway between Kompolje and Blagovica (Fig. 1; Horvat et al. 2014a; 2014b).

The Črni graben valley is the easiest passage between central and eastern Slovenia and was used as such for centuries. In the $1^{\text {st }}$ century $\mathrm{AD}$, Romans built a via publica through the valley, which became the main road between Italy and the Danube Regions until the $12^{\text {th }}$ century, when the main road was moved north to the Tuhinjska dolina valley. The Črni graben road again became the most important road between the Adriatic and the Danube from the end of the $16^{\text {th }}$ century and is still being used today (Stražar 1985.626).

The excavation site covers an area of $237 \mathrm{x} 15 \mathrm{~m}$ and is located directly on the alluvial beds of two torrents that flowed from the hills in the north to the Radomlja River in the south. The old torrent bed in the western part was filled with Eneolithic pottery, and two partly preserved kilns were dug into the youngest Eneolithic layer on the bank. Only the floor of the kiln remained intact. Charcoal and some pieces of pottery were documented on the floor of the kiln. The eastern torrent bed was also filled with Eneolithic pottery, some charcoal, parts of grind stones, and a stone mallet and an axe (Horvat et al. 2014a. 67; 2014b).

The charcoal from the infill of the stream, from the Eneolithic layer, and from the kiln was AMS radiocarbon dated at the Poznan Radiocarbon Laboratory. According to the ${ }^{14} \mathrm{C}$ dates the calendar age of the Eneolithic material can be placed within the $37^{\text {th }}$ $35^{\text {th }}$ century calBC range, while the two kilns date to the late $37^{\text {th }}$ and/or $36^{\text {th }}$ century calBC; both the kiln samples show the same ${ }^{14} \mathrm{C}$ age of $4750 \pm 35 \mathrm{BP}$ (Tab. 1; Horvat et al. 2014a.69; 2014b). This makes Krašnja contemporaneous with sites in the Ljubljansko barje region, especially with Maharski prekop (Bregant 1974a; 1974b; 1975; Mlekuž et al. 2012) and Hočevarica (Velušček 2004).

\section{Pottery technology and typology}

We described the pottery assemblage at the macroscopic level with the use of a hand lens to identify

\begin{tabular}{|lccccc|}
\hline Lab. No. & Material & Context & $\begin{array}{c}\text { 14C Conventional } \\
\text { age BP }\end{array}$ & $\begin{array}{c}\text { Calibrated age } \\
\text { calBC (68.2\%) }\end{array}$ & $\begin{array}{l}\text { Calibrated age } \\
\text { calBC (95.4\%) }\end{array}$ \\
\hline Poz-58839 & charcoal & layer SU 21 & $4655 \pm 35$ & $3510-3365$ & $3620-3360$ \\
\hline Poz-58840 & charcoal & layer SU 137 & $4820 \pm 35$ & $3650-3535$ & $3695-3520$ \\
\hline Poz-58841 & charcoal & kiln SU 136 & $4750 \pm 35$ & $3635-3515$ & $3640-3380$ \\
\hline Poz-58842 & charcoal & kiln SU 117 & $4750 \pm 35$ & $3635-3515$ & $3640-3380$ \\
\hline Poz-58843 & charcoal & layer SU 214 & $4910 \pm 35$ & $3710-3650$ & $3770-3640$ \\
\hline Poz-58845 & charcoal & layer SU 198 & $4930 \pm 40$ & $3765-3650$ & $3790-3645$ \\
\hline Poz-58846 & charcoal & layer SU 172 & $4870 \pm 40$ & $3695-3635$ & $3765-3530$ \\
\hline
\end{tabular}

Tab. 1. ${ }^{14} \mathrm{C}$ dates for the Eneolithic period at Krašnja. 
Pots
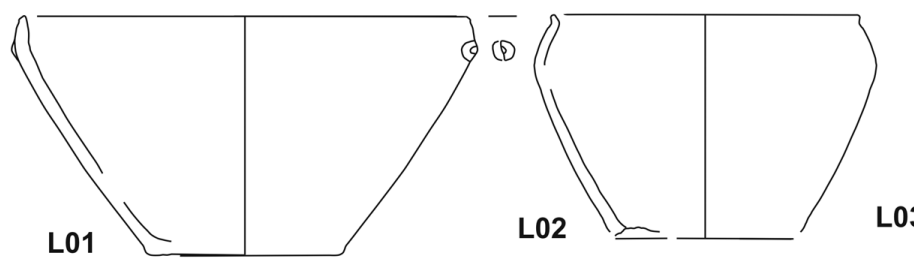

L03a

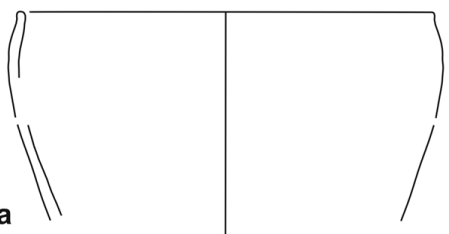

L04

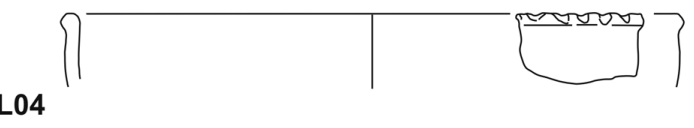

\section{Bowls}

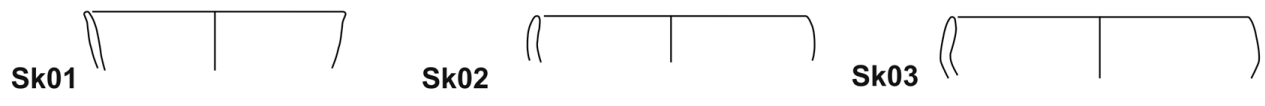

\section{Dishes}
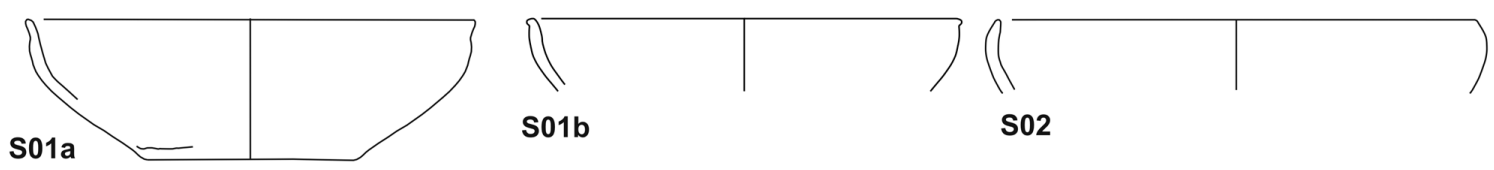

S01b

S02

\section{Cups}
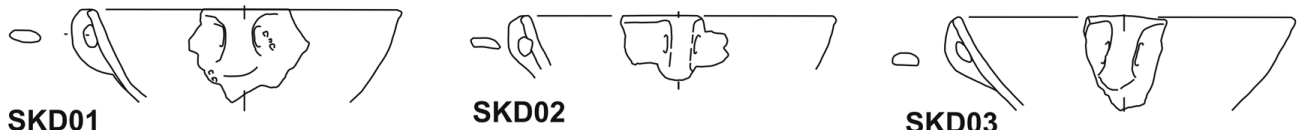

\section{Beakers}
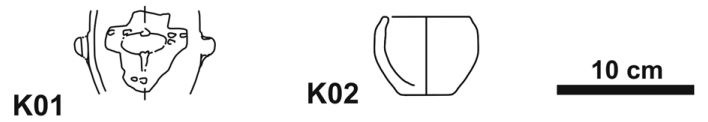

Fig. 2. Pottery typology of Eneolithic vessels from Krašnja.

inclusions, their size and frequency, the presence of voids, as well as hardness, colour after firing, and the firing atmosphere of the vessels (following descriptions after Horvat 1999). Because the vessels were fragmented to a great extent, the technological description was made only of typologically defined vessels and fragments of vessel rims, bases, and ornamented fragments. All the analysed pottery could be attributed to a single technological group, i.e. fine- grained fabric with quartz inclusions. The other inclusions are mica, ferrous oxides, organic matter and very rare crushed pottery or grog.

All the vessel surfaces are burnished and well formed, but also have many voids visible on the surface. The voids have angular and semi-angular shapes, and measure from 0.5 to $2 \mathrm{~mm}$. The majority of vessels $(77 \%)$ were fired in an incomplete oxidising atmosphere, while the rest were fired in an oxidising atmosphere. The vessels have mostly grey and light brown surface colours, with rare fragments in red, grey and dark brown shades.

A total of 329 fragments of pottery were excavated at Krašnja in the Eneolithic assemblage, from which only 25 whole vessels could be reconstructed and assigned to five basic types: pots (11), dishes (5), bowls (3), cups (4) and beakers (2). Among the unclassified pottery fragments are mostly parts of vessel bases and parts of walls with hand-made appliqués. This classification was made using criteria such as shape and proportions (Horvat 1999). The Eneolithic pottery from Krašnja has many similarities with assemblages from contemporary sites in the Ljubljansko barje region, mostly with Maharski prekop (Bregant 1974a; 1974b; 1975), Hočevarica (Velušček 2004) and Stare gmajne (Velušček 2009). 
Pots (Fig. 2) are classified into two groups according to their outline and the shape of the contact between the upper and lower parts of the vessels. The first group is comprised of pots without necks, with biconical (L01, L02) or ellipsoid shape (L03a, L03b, L04). The second group of pots is comprised of vessels with necks. At Krašnja, only the upper parts of these vessels were preserved, so a reconstruction of the shapes was not possible.

The biconical shapes present a special form of pot with a high bottom part and short shoulders. These pots were common in the Eneolithic period in central Slovenia. Pot variant L01 can be found at Hočevarica (Velušček 2004.t. 4.1.5:7) and pot variant L02 at Hočevarica (Velušček 2004.186, Fig. 4.2.1:L2) and Maharski prekop (Bregant 1974a.t. 3.8). For variant $\mathrm{L} 03 \mathrm{a}$ and $\mathrm{L} 03 \mathrm{~b}$, there are comparisons at Maharski prekop (Bregant 1974a.t. 5.4; 1975.t. 30.11) and Hočevarica (Velušček 2004.186, Fig. 4.2.1:L3).

We used functional criteria (e.g., open/closed, deep/ shallow) and the criteria of the vessels outlines to classify dishes and bowl (Fig. 2). Dishes are classified into open shallow dishes with a biconical outline with a semi-ellipsoid shape and a redesigned rim and a sharp contact with the wall of the vessel (S01a, S01b). Dishes S01a and S01b have parallels from Hočevarica (Velušček 2004.t. 4.1:6, t. 4.1.8:5) and from Maharski prekop (unpublished material). Only one type is a deep closed dish with a complex biconical outline with a semi-ellipsoid shape and a simple rim (S02). Variant S02 has parallels with a dish from Maharski prekop (Bregant 1975.t. 22.10).

Only three bowls could be classified in the assemblage (Fig. 2). The most significant is an open bowl with an oblique rim that has a fluid contact with the lower part of the body with a spherical shape (Sk01). Bowls similar to Sk01 can be found at Hočevarica (Velušček 2004.Fig. 4.2.9:S8), Maharski prekop (Bregant 1975.t. 19.4) and Stare gmajne (Velušček 2009. $t$. 3.18:9). Among the closed shapes of bowls, we could identify a bowl with a simple spherical shape (Sk02) and a biconical bowl with a conical spherical shape (Sk03), both with a simple rim and fluid contact with the body. Similarities to bowls of variant Sk02 are also found at Hočevarica (Velušček 2004. t. 4.1.2:9) and Maharski prekop (Bregant 1975.t. 28.9).

Cups and beakers are classified between shallow and deep vessel types (Fig. 2). The variants Skd01 and Skd02 are open bowls with a simple spherical out- line, and variant Skd03 is an open bowl with a conical shape, an oblique rim and gradual contact with the lower part of the body. The cups Skd01 are similar to cups from Hočevarica (Velušček 2004.t. 4.1.2:9). The beakers have a simple ellipsoid shape (K01) or a biconical outline with a semi-ellipsoid shape (K02). Beakers K01 have similarities with vessels from Hočevarica (Velušček 2004.196, Fig. 4.2.7: K4) and K02 can also be found at Maharski prekop (unpublished material) and Stare gmajne (Velušček 2009.t. 3.15: 11, Fig. 3.15: K1).

The vessels are only modestly decorated, with only two basic types of decoration: impressions and appliqués. The most common techniques are awl impressing, pinching with two fingers, and simple hand-made appliqués; the latter two were also identified in combination.

\section{Analytical methods}

The Krašnja pottery was first analysed with the use of a hand lens and described at the macroscopic level, detailing the broader technological traits of the whole assemblage (Horvat 1999) such as the inclusions, their size and abundance, the presence of voids, the hardness, surface treatment, colour, and firing atmosphere. The pottery was then sampled according to its stratigraphic position, vessel type and ornamentation technique, and basic technological traits. We sampled 12 vessels from the Eneolithic period and three additional contemporary clay samples from the excavated kiln SU 117 at the site (Tab. 2).

For the mineralogical analyses, we used thin-section petrography and X-ray powder diffraction techniques. Ceramic petrography enhances the identification of non-plastic inclusions and allows for direct comparisons with regional geology (Rice 1987.415; Whitbread 1995). The pottery samples were prepared as standard thin sections of $30 \mu \mathrm{m}$ thickness (Reedy 2008.1-3) and then described under a polarising light microscope (Whitbread 1995.App. 3; Terry, Chillingar 1955). One of the clay samples from kiln SU 117 was fired in a controlled atmosphere to $800^{\circ} \mathrm{C}$ and prepared as a thin section.

We sorted the samples into fabric groups based on the composition of inclusions, the clay matrix and voids. On the basis of compositional, microstructural and textural criteria, we identified the presence of specific techniques, such as the addition of temper, raw material processing, vessel forming, and the at- 


\begin{tabular}{|lccccl|}
\hline Sample No. & $\begin{array}{c}\text { Catalogue } \\
\text { No. }\end{array}$ & SU & $\begin{array}{c}\text { Grid } \\
\text { Square }\end{array}$ & $\begin{array}{c}\text { Vessel } \\
\text { Type }\end{array}$ & Description \\
\hline OBD 16 & 13 & 21 & F38 & So1b & dish \\
\hline OBD 180 & 2 & 21 & G38 & Lo2 & pot \\
\hline OBD 181 & 20 & 242 & E36 & Ko2 & beaker \\
\hline OBD 183 & 1 & 21 & E39 & LO3b & pot \\
\hline OBD 184 & 35 & 21 & E38 & $/$ & vessel (base) \\
\hline OBD 245 & 17 & 21 & G38 & SKD03 & cup \\
\hline OBD 247 & 18 & 21 & E38 & SKDo1 & cup \\
\hline OBD 248 & 19 & 21 & E39 & Ko2 & beaker \\
\hline OBD 249 & 15 & 21 & E39 & SKDo2 & cup \\
\hline OBD 251 & 14 & 21 & E33 & SO2 & dish \\
\hline OBD 252 & 10 & 21 & E38 & So1a & dish \\
\hline OBD 258 & 6 & 21 & G38 & Lo4 & pot \\
\hline Sample 17 & $/$ & 117 & E27 & $/$ & fired clay - part of kiln roof \\
\hline Sample 18 & $/$ & 117 & E27 & $/$ & fired clay - kiln floor \\
\hline Sample 28 & $/$ & 117 & E27 & $/$ & clay - part below the kiln \\
\hline
\end{tabular}

Tab. 2. List of pottery and kiln samples from Krašnja.

mosphere and firing temperatures (Reedy 2008.146148, 173-189; Whitbread 1986; 1995.393).

The pottery and clay samples were also analysed using the X-ray powder diffraction method. For the analysis, approx. $3 \mathrm{~g}$ of pottery were ground into fine powder and then recorded on a Philips PW3710 Xray diffractometer ( $\mathrm{Cu}$ X-ray tube; secondary graphite monochromator; $10 \mathrm{kV} ; 10 \mathrm{~mA} ; 2$ to $70^{\circ} 2 \theta$ ).

\section{The results of ceramic petrography and X-ray diffraction}

The petrographic analysis revealed many similarities with the pottery samples from Krašnja. The pottery was made from non-calcareous clay, with many inclusions, such as quartz, mica (muscovite, sericite, biotite), plagioclase feldspars and composed mineral grains such as chert, opaque aggregates, argillaceous rock fragments and, very rarely, organic matter. The main difference between the samples is in their microfossil content and the presence of opaque minerals. We could divide the samples into 5 fabrics according to their composition (Tab. 3).

The samples have very few (1-5\%) angular voids, mostly in the medium to coarse sand size fraction, with many of them having a rhombohedral shape characteristic of calcite crystals. Based on their shape, we conclude that these voids were created as a result of dissolving calcite from pottery (e.g., Fig. 4.D). Since voids are mostly sand grained with almost no voids in the silt size fraction common to non-plastic inclusions, this confirms that calcite was added to the clay paste as temper. The dissolution of calcium carbonate may occur in post-deposition of pottery due to the low $\mathrm{pH}$ environment of the soil (Reedy 2008.208). Afterwards, the voids were secondarily coated with amorphous hydrated iron oxide-hydroxides, i.e. limonite (Fig. 3). Such chemical alterations and deterioration in the composition of pottery are common postdepositional processes when vessels are buried in sediment (Rice 1987.421; Reedy 2008. 208-210).

Fabric 1 (Fig. 4.A) is a non-calcareous clay with frequent (30\%) non-plastic inclusions that are well sorted and mostly in the silt size fraction. They include frequent monocrystalline quartz, common muscovite mica grains and opaque ferrous minerals, and rare biotite mica, plagioclase feldspars and chert. Microfossil sponge spicules are also common in the paste (10\%). The fabric has rare (1\%) angular and rhombohedral voids, showing that the crushed calcite was added to the fabric as temper. The fabric was recognised in only one beaker from the Eneolithic layer (OBD 248).

Fabric 2 (Fig. 4.B) is a non-calcareous clay with common $(20 \%)$ non-plastic inclusions that are well sorted and mostly in the silt size fraction. They include common monocrystalline quartz, common muscovite

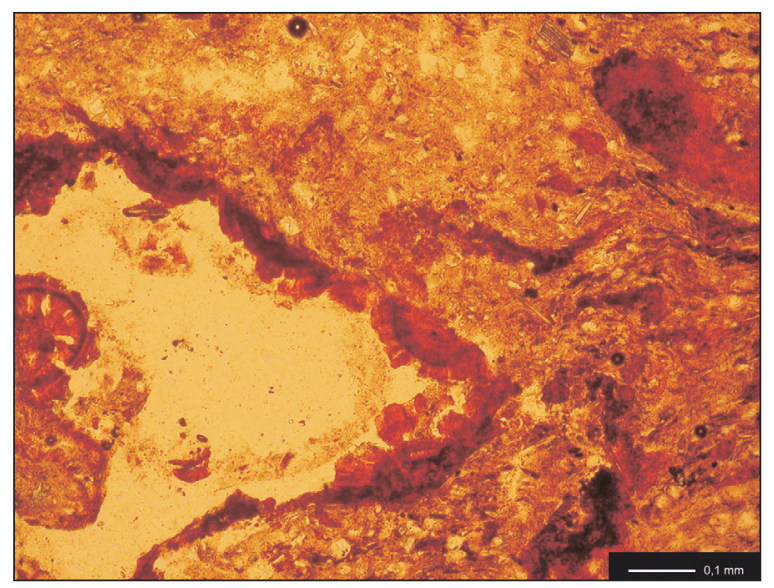

Fig. 3. Photomicrograph of a thin-section from cup OBD 245 from Krašnja. The voids in the sample are secondarily coated with amorphous limonite. Image taken in plane polarised light. 


\begin{tabular}{|c|c|c|c|c|c|c|c|c|}
\hline & $\begin{array}{l}\text { Voids } \\
\text { (in \%) }\end{array}$ & $\begin{array}{l}\text { Grog } \\
\text { (in \%) }\end{array}$ & $\begin{array}{l}\text { Quartz } \\
\text { (in \%) }\end{array}$ & $\begin{array}{l}\text { Mica } \\
\text { (in \%) }\end{array}$ & $\begin{array}{c}\text { Spicules } \\
\text { (in \%) }\end{array}$ & $\begin{array}{c}\text { Diatoms } \\
\text { (in \%) }\end{array}$ & $\begin{array}{c}\text { Opaques } \\
\text { (in \%) }\end{array}$ & Sample No. \\
\hline Fabric 1 & 1 & I & 40 & 20 & 10 & o & 10 & OBD 248 \\
\hline Fabric 2 & 5 & $0-1$ & $20-30$ & 20 & $10-15$ & $0-2$ & 10 & OBD 16, OBD 247, OBD 251 \\
\hline Fabric 3 & 1 & I & 20 & 5 & 10 & 2 & 30 & OBD 184 \\
\hline Fabric 4 & $1-5$ & $0-1$ & $30-40$ & $5^{-15}$ & $10-15$ & $5-10$ & $5-15$ & $\begin{array}{l}\text { OBD } 181, \text { OBD } 183, \text { OBD } \\
245, \text { OBD } 252, \text { OBD } 258\end{array}$ \\
\hline Fabric 5 & 1 & l & $20-30$ & $10-20$ & 10 & 15 & 10 & OBD 180, OBD 249 \\
\hline
\end{tabular}

\section{Tab. 3. The basic compositions of pottery fabrics from Krašnja.}

mica grains and opaque ferrous minerals, and rare biotite mica, chert and organic matter. Common (10$15 \%)$ sponge spicules and rare (0-2\%) diatoms microfossils are also present in the paste. The fabric has few (5\%) angular and rhombohedral voids, showing that the crushed calcite was added to the fabric as temper. The fabric was recognised in two dishes (OBD 16, OBD 251) and one cup (OBD 247). Dish OBD 251 also had rare (1\%) angular grains in the coarse sand size (approx. 1mm) composed of noncalcareous clay with quartz and mica inclusions and sponge spicules. These grains could be attributed to crushed old pottery (i.e. grog) added to the fabric as temper.

Fabric 3 (Fig. 4.C) is a non-calcareous clay with common (20\%) non-plastic inclusions that are well sorted and mostly in the silt size fraction. They include common monocrystalline quartz, a few muscovite mica grains, frequent opaque ferrous minerals, and rarely, biotite mica grains. Common (10\%) sponge spicules and few diatoms $(2 \%)$ are also present in the paste. The fabric has rare (1\%) angular and rhombohedral voids, showing that the crushed calcite was added to the fabric as temper. The fabric was recognised only in one sample, i.e. a fragment of a base (OBD 184).

Fabric 4 (Fig. 4.D) is the most common fabric, since five samples could be attributed to it. The samples include two pots (OBD 183, OBD 258), a dish (OBD 252), a beaker (OBD 181) and a cup (OBD 245). They are made of non-calcareous clay, with common to frequent $(20-30 \%)$ non-plastic inclusions that are well sorted and in the silt size fraction. They include frequent monocrystalline quartz, few to common muscovite mica grains and opaque ferrous minerals, and rare biotite mica, plagioclase feldspars and chert. Common sponge spicules (10$15 \%)$ and diatoms (5-10\%) are also present in the paste. The fabric has rare to few (1-5\%) angular and
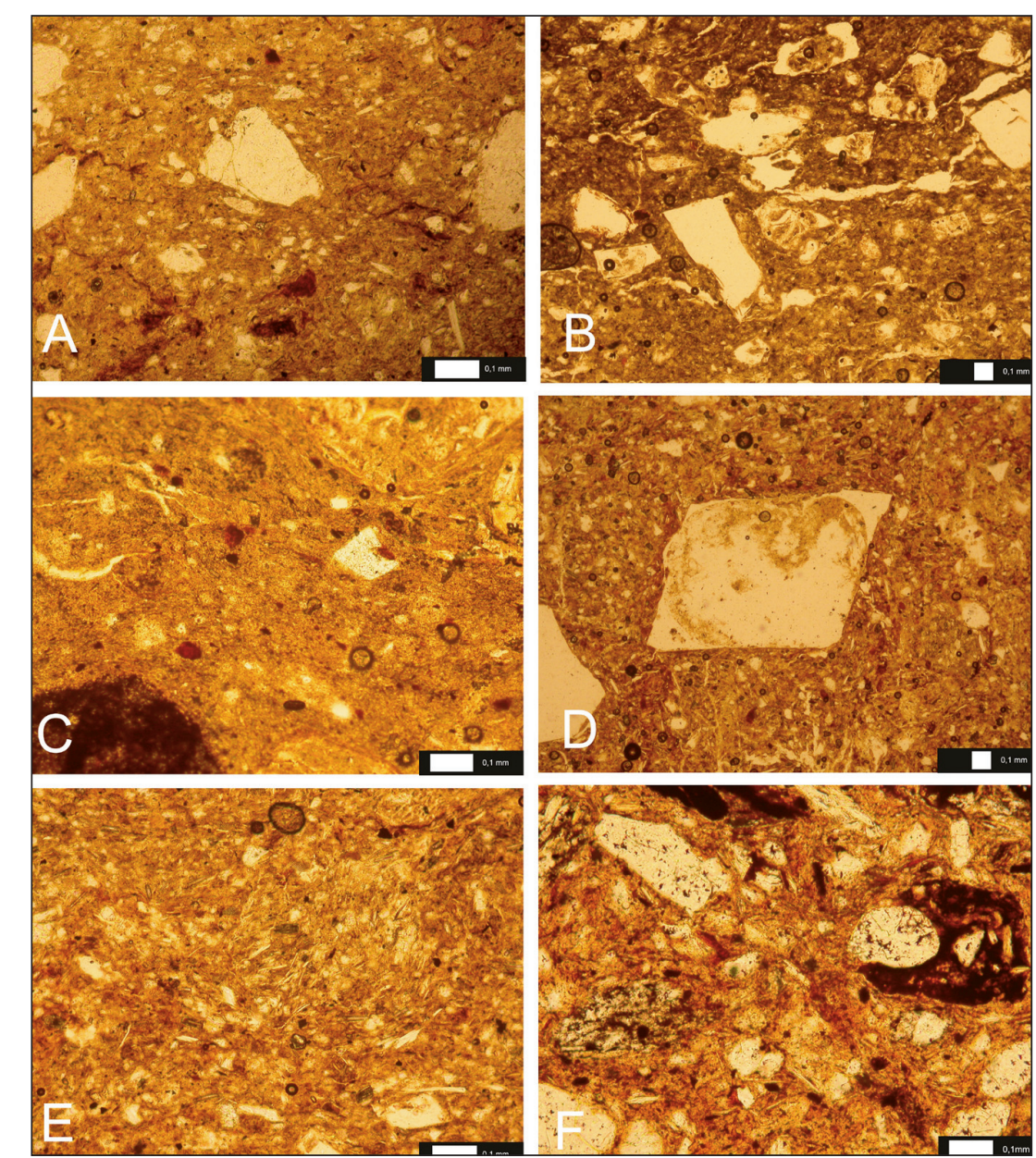

Fig. 4. Photomicrographs of pottery thin-sections from Krašnja: A - fabric 1 (beaker OBD 248); B - fabric 2 (dish OBD 251); C - fabric 3 (vessel OBD 184); D - fabric 4 (pot OBD 258); E - fabric 5 (pot OBD 180); F fired sample 28 from kiln SU 117. Images taken in plane polarised light. 
rhombohedral voids, showing that the crushed calcite was added to the fabric as temper. Beaker OBD 181 also had rare (1\%) angular grains in the coarse grain size (approx. $1 \mathrm{~mm}$ ) that are composed of noncalcareous clay with quartz and mica inclusions, as well as sponge spicules and diatoms. These could be attributed to crushed grains of ceramic vessels (i.e. grog) added to the fabric as temper.

Fabric 5 (Fig. 4.E) is a non-calcareous clay with frequent (30\%) non-plastic inclusions that are well sorted and mostly in the silt size fraction. They include common monocrystalline quartz, mica (muscovite) grains and opaque ferrous minerals, as well as very rare biotite mica, plagioclase feldspars and chert. Diatoms comprise $15 \%$ of all inclusions and are slightly more common than sponge spicules (10\%). The fabric has rare (1\%) angular and rhombohedral voids, showing that the crushed calcite was added to the fabric as temper. The fabric could be recognised in two samples, i.e. pot OBD 180 and cup OBD 249.

The various fabrics were all made to a similar recipe, since they all contain added calcite temper that was later dissolved from the vessels. Pottery recipes with added calcite temper also comprise the most common type of pottery from the contemporary site at Maharski prekop near Ig in the Ljubljansko barje region (Osterc 1975; Žibrat Gašparič 2013.153155). Only two samples had crushed old pottery or grog added as temper in addition to crushed calcite grains, i.e. beaker OBD 181 and dish OBD 251. A similar recipe with calcite and grog was also discovered at Maharski prekop, which has a rare type of fabric (Osterc 1975; Žibrat Gašparič 2013.153-155). The presence of added calcite is a common temper in cooking pots, since the shape and properties of these grains give a vessel greater thermal and shock resistance than quartz temper (Tite et al. 2001).

The microfossils present in the samples are isotropic, have oval to spherical cross-sections and range from 20 to $100 \mu \mathrm{m}$ in size (Fig. 5). These are mostly fragmented remains of siliceous sponge spicules and diatoms (Quinn 2008). Their shapes suggest that the sponges and diatoms were saltwater organisms originating from sedimentary rocks, perhaps from local Middle Miocene marlstone (Aleksander Horvat, pers. comm.). Diatomaceous sediments are rare in Slovenia and could be confirmed only for some Middle Miocene sedimentary rocks from central Slovenia (Horvat, Mišič 2004). Nevertheless, Miocene sedimentary rocks can be found closest to Krašnja in the two valleys parallel to Črni graben and the valley of the Radomlja River: i.e. in the northern Tuhinjska dolina valley and in the south near Moravče and Izlake (Premru 1983).

The X-ray powder diffraction analysis shows even greater similarities between the pottery samples than the results of petrography (Tab. 4). All the samples have similar peaks of minerals such as quartz, muscovite mica and plagioclase feldspars (albite and/or anorthite).

As we have demonstrated, the most common recipe at Krašnja has crushed calcite grains added to the fabric. At temperatures around $850^{\circ} \mathrm{C}$, calcite $\left(\mathrm{CaCO}_{3}\right)$ starts to decompose into lime $(\mathrm{CaO})$, although the reaction can start as low as $700^{\circ} \mathrm{C}$ according to tests (Cultrone et al. 2001.628). This reaction can damage vessels in the cooling process. Since the vessels at Krašnja were not damaged during firing and were being used, they were clearly fired below 700 to $800^{\circ} \mathrm{C}$. The absence of clay minerals and clinochlore as well as the presence of cracked quartz grains, attributed to the quartz inversion reaction at $573^{\circ} \mathrm{C}$ (Graimshaw 1971.221-227), show the lower firing temperatures of the Krašnja samples were around $600^{\circ} \mathrm{C}$.

\section{Analysis of kiln SU 117}

The remains of two kilns were excavated at Krašnja (SU 136 and SU 117; Horvat et al. 2014). Only the fired floors of the chamber and part of the firebox facing west were preserved, since the kilns were partly destroyed by water erosion. Nevertheless, the remains show that the kilns had spherical shape (Fig. 6) and could be the remains of a simple updraft kiln (Rye 1981.100; Rice 1987.159-160). The surface of

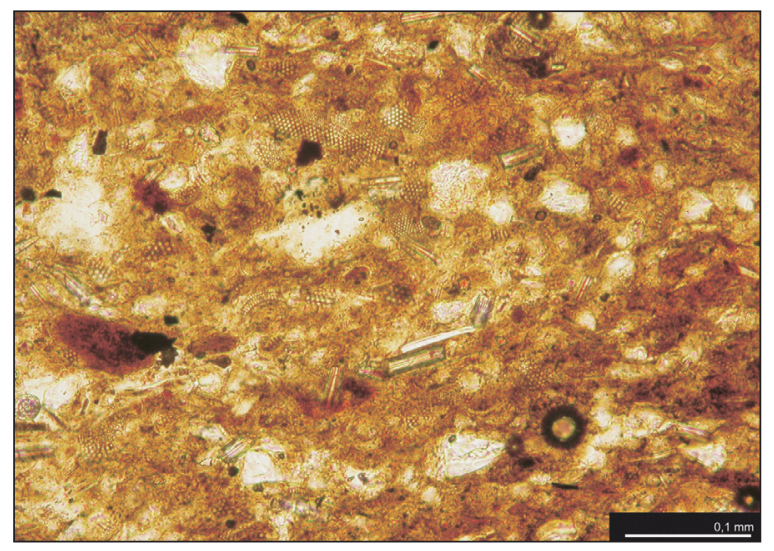

Fig. 5. Photomicrograph of a thin-section from pot $O B D 180$ from Krašnja. The image shows the presence of sponge spicules and diatoms inside the clay matrix. Image taken in plane polarised light. 
the chamber was later filled with dark grey-brown silt with pieces of charcoal and Eneolithic pottery. The radiocarbon dates of charcoal from both kilns date the material to the second half of the $37^{\text {th }}$ and/ or the $36^{\text {th }}$ century calBC (Tab. 1).

We analysed three samples from kiln SU 117, including one fired clay sample from the floor of the kiln, one from the roof and one sample of partly fired clay from beneath the kiln (Tab. 2). Sample 28 is a light yellowish brown fired clay from below the floor of the kiln; sample 18 is a reddish brown fired clay from the central floor of the kiln, and sample 17 is a brown fired clay from the roof part of the kiln. The samples were dried and prepared for X-ray powder diffraction analysis.

The mineralogical composition of all three samples is very similar (Tab. 4), as according to the analysis they all contain minerals such as quartz, muscovite mica, plagioclase feldspars and clinochlore. The clay samples are similar to pottery; only the presence of clinochlore in the samples points to a lower firing temperature than the temperature achieved in pottery from Krašnja. Clinochlore starts to decompose at 500 to $600^{\circ} \mathrm{C}($ Grimshaw 1971.221- 227). Therefore, we conclude that the temperatures inside the kiln wall did not exceed $500^{\circ} \mathrm{C}$ for most of the firing process. Since the Eneolithic pottery from Krašnja was fired above this temperature and showed no presence of clinochlore, we could presume that the kiln was not used to fire pottery. Nevertheless, we have to bear in mind that temperatures inside a kiln can be a few hundred degrees higher than temperatures during kiln construction (Rye 1981.102-103; Harrison 2008; Urankar 2012; Kramar 2013).

Sample 28 was additionally fired in a controlled oxidising atmosphere at $800^{\circ} \mathrm{C}$ and prepared as a standard thin section for petrographic analysis. The aim of this analysis was to establish a comparison between the Eneolithic pottery samples and this in situ clay sample from a contemporaneous kiln. The fired test sample had a reddish yellow colour and Mohs hardness 4 . The sample is a non-calcareous clay, with frequent (40\%) non-plastic inclusions, mostly in the silt size fraction (Fig. 4.F). These include frequent monocrystalline quartz, common muscovite mica and frequent opaque ferrous mine- rals. There are also a few (5\%) polycrystalline quartz grains present, such as sandstone grains and chert, and rarely, other minerals such as biotite mica, plagioclase feldspars, microcline alkali feldspars, argillaceous rock fragments and organic matter. Clay sample 28 had no traces of microfossils such as sponge spicules or diatoms.

Samples 17, 18 and 28 from kiln SU 117 have a similar mineralogical composition to the Eneolithic pottery; however, as demonstrated by the test-fired sample 28 , the clay samples were more coarse grained, contained more polycrystalline quartz and muscovite mica than the pottery, and had no traces of sponge spicules or diatoms characteristic of the Krašnja pottery. We conclude that the potters at Krašnja obtained clay for their vessels from a different source, and did not use the clay that was available at the site. As already mentioned, the microfossils found in the pottery had to come from material outside the Črni graben valley, since such rocks are not part of the local geology.

For additional provenance analysis, we sampled two more clays, one obtained near Krašnja (sample KR) and one near Moravče (sample MO). The first clay sample came from sediments excavated during the construction of the renewed pipeline, some $100 \mathrm{~m}$ east of the archaeological excavation site. The second sample was obtained from a Miocene quartzsand quarry near Moravče, some $5 \mathrm{~km}$ south of Krašnja in the neighbouring valley, where layers of plastic clay can be found between the sand (Rokavec 2014.79). The samples were fired in a controlled oxidising atmosphere at $700^{\circ} \mathrm{C}, 800^{\circ} \mathrm{C}$ and $900^{\circ} \mathrm{C}$, and then prepared as standard thin sections for petrographic analysis.

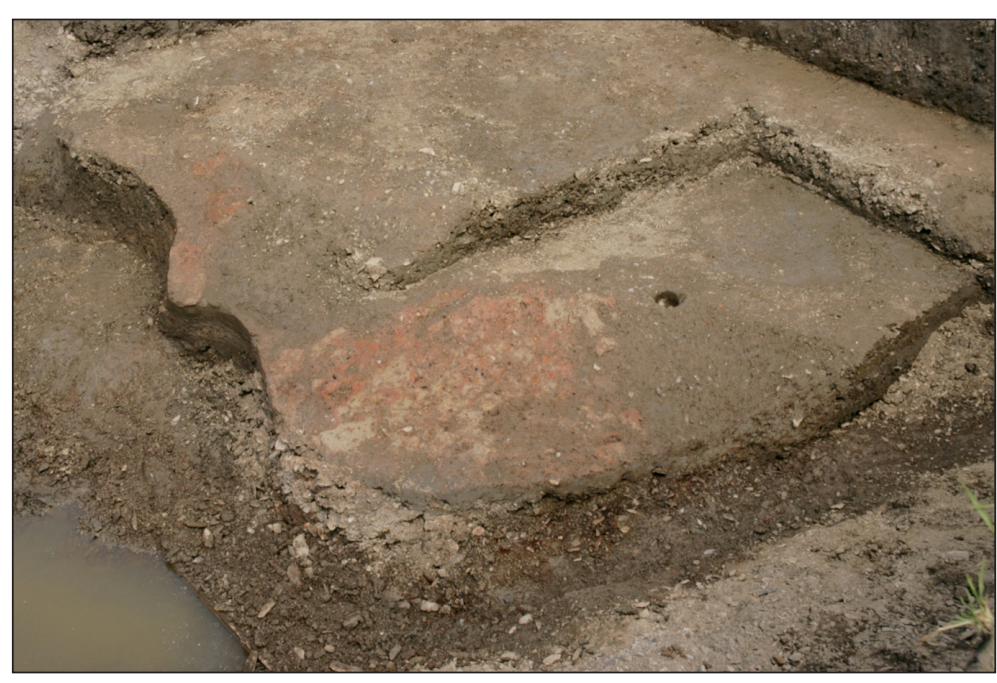

Fig. 6. Partly preserved Eneolithic kiln SU 117 from Krašnja. 


\begin{tabular}{|l|c|c|c|c|}
\hline Sample No. & Quartz & Muscovite & Clinochlore & Plagioclase \\
\hline OBD 16 & $\mathrm{x}$ & $\mathrm{x}$ & & $\mathrm{x}$ \\
\hline OBD 180 & $\mathrm{x}$ & $\mathrm{x}$ & & $\mathrm{x}$ \\
\hline OBD 181 & $\mathrm{x}$ & $\mathrm{x}$ & & $\mathrm{x}$ \\
\hline OBD 183 & $\mathrm{x}$ & $\mathrm{x}$ & & $\mathrm{x}$ \\
\hline OBD 184 & $\mathrm{x}$ & $\mathrm{x}$ & & $\mathrm{x}$ \\
\hline OBD 245 & $\mathrm{x}$ & $\mathrm{x}$ & & $\mathrm{x}$ \\
\hline OBD 247 & $\mathrm{x}$ & $\mathrm{x}$ & & $\mathrm{x}$ \\
\hline OBD 248 & $\mathrm{x}$ & $\mathrm{x}$ & & $\mathrm{x}$ \\
\hline OBD 249 & $\mathrm{x}$ & $\mathrm{x}$ & & $\mathrm{x}$ \\
\hline OBD 251 & $\mathrm{x}$ & $\mathrm{x}$ & & $\mathrm{x}$ \\
\hline OBD 252 & $\mathrm{x}$ & $\mathrm{x}$ & & $\mathrm{x}$ \\
\hline OBD 258 & $\mathrm{x}$ & $\mathrm{x}$ & & $\mathrm{x}$ \\
\hline Sample 17 & $\mathrm{x}$ & $\mathrm{x}$ & $\mathrm{x}$ & $\mathrm{x}$ \\
\hline Sample 18 & $\mathrm{x}$ & $\mathrm{x}$ & $\mathrm{x}$ & $\mathrm{x}$ \\
\hline Sample 28 & $\mathrm{x}$ & $\mathrm{x}$ & $\mathrm{x}$ & $\mathrm{x}$ \\
\hline
\end{tabular}

Tab. 4. The mineralogical composition of pottery and clay samples from Krašnja after X-ray diffraction analysis.

The preliminary petrographic results show that clay KR near Krašnja contained more frequent mica grains and no microfossils in the matrix and differs considerably from the Eneolithic pottery found at the site, thus confirming that Krašnja potters obtained their raw material outside the Crni graben valley. Sample MO has more similarities with the Eneolithic pottery, which the petrographic results predicted, but contained only very rare remains of sponge spicules. The question of whether clay from the Moravče valley or some other material was used to produce the pottery at Krašnja will have to be answered in the future with additional samples.

\section{Discussion}

The technological choices of potters are always linked to natural resources, the cultural traditions of their community and its natural backdrop. Therefore, the choices of natural materials, ceramic fabrics and recipes, firing conditions and ways of forming vessels are linked to the local environment as much as to the abilities and experience of the potters (Sillar, Tite 2000.7-9). But they are also linked to culturally defined pottery traditions that reveal symbolic gestures or individuality of the potters, which can be postulated, for example, in the use of old vessels as an integral part of a new pot (Quinn, Burton 2009.288). Similarly, the use of crushed calcite can be seen as a purely technological choice, since lowfired vessels with a high calcite temper perform better as cooking vessels due to the higher resistibility to changes in temperature needed in cooking ves- sels (Tite et al. 2001), but could be also linked to a special role of this mineral in a community, e.g. calcite was used for making ornaments in the Eneolithic period (Žibrat Gašparič 2013).

Both these techniques were documented at Krašnja. Most of the pottery was made of fine-grained material with added crushed calcite as temper, with only few pots with both added crushed calcite and old pottery as temper. A similar technology was documented at the Maharski prekop site in the Ljubljansko barje region, where the addition of crushed calcite is the most common pottery recipe in the Eneolithic period, while pottery with added calcite and grog is also present (Osterc 1975; Žibrat Gašparič 2013). The main difference between Krašnja and Maharski prekop pottery is the mineral composition of the clay matrix, the presence of microfossils at Krašnja, and the different firing atmospheres documented for each site, i.e. oxidizing conditions at Krašnja and reducing atmosphere at Maharski prekop (Žibrat Gašparič 2013).

The non-calcareous clays used for making vessels at Krašnja had a similar composition of quartz, mica, feldspars, chert, opaque ferrous minerals and several remains of microfossils, i.e. sponge spicules and diatoms. According to changes in the composition, we could define 5 different fabrics, although the main mineralogical composition in the fabrics is quite similar, as shown by the petrography and $\mathrm{X}$ ray diffraction. The observed variations between the fabrics could be the result of fluctuations in composition between the different locations of clay pits, but also within a single clay pit (Fig. 4; Tabs. 3-4).

The shape of diatoms and sponge spicules inside the clay suggest that they belonged to saltwater species of these organisms (Fig. 5). These organisms therefore did not live in a freshwater environment of the Eneolithic period, as is the case of sponge spicules documented at the Neolithic site at Resnikov prekop in the Ljubljansko barje, but represent the remains of weathered sedimentary rocks, most probably from marlstones of the Miocene age (Aleksander Horvat, pers. comm.). The surrounding geology of Krašnja has no Miocene rock formations, but they are present in two valleys less than $10 \mathrm{~km}$ from Krašnja: in the Moravče valley to the south and the Tuhinjska dolina valley to the north (Premru 1983). This distance is still within the area of the site-catchment proposed for traditional potters (Arnold 1985). The clay material used in the construction of the Eneolithic kiln SU 117 found in situ at Krašnja (Fig. 
6) had a different composition than the Krašnja pottery, especially lacking any remains of microfossils (Fig. 4.F), which is additional proof that natural materials available around Krašnja were not used for pottery production. This is also supported by two additional clay samples, one obtained near Krašnja and one from a Miocene quarry near Moravče in the south.

The clay was then shaped into various types of vessels. At Krašnja we could document types such as pots, dishes, bowls, cups and beakers that were only rarely decorated (Fig. 2). For the shaping of different vessels, the Krašnja potters used various fabrics, but mostly only one recipe, i.e. with added calcite as mentioned above. Pots were made with fabrics 3, 4 and 5, dishes with fabrics 2 and 4; cups were made with fabrics 2,4 and 5 , and beakers with fabrics 1 and 4 . This proves that the same fabrics and recipes were used for a variety of vessels, e.g., fabric 4 was the main component of pots, dishes, cups and beakers alike (Tabs. 2-3). The vessels were then dried and fired usually in an incomplete oxidising atmosphere, probably inside kilns such as were excavated at the site. These vessels share many similarities in pottery typology and technology with material from contemporaneous sites such as Hočevarica, Maharski prekop and Stare gmajne in the Ljubljansko barje region (Bregant 1974a; 1974b; 1975; Velušček 2004; 2009; Mlekuž et al. 2012; Žibrat Gašparič 2013).

The story of pottery from Krašnja did not end with the discarding of pots and deposition. The depositional conditions of the sediments where the vessels lay for thousands of years have changed its composition significantly. Chemical alterations are common in vessels in a buried environment (Rice 1987. 421). The crushed calcite grains that were added as temper were not preserved inside the pots, but dissolved; all that is left behind is the typical rhombo- hedral shape and size of the voids (Fig. 4.D). A similar event was documented with a petrographic analysis of Eneolithic pottery from Moverna vas in the Bela Krajina region in southern Slovenia, where the dissolution of calcite could be connected to very acid soils (Žibrat Gašparič 2008.127-174). In addition, the remaining voids inside the vessels from Krašnja were then secondarily coated with amorphous hydrated iron oxide-hydroxides, i.e. limonite (Fig. 3).

\section{Conclusions}

The mineralogical and petrographic analyses of Eneolithic Krašnja pottery showed that the vessels were made with at least 5 different fabrics that nevertheless have a similar mineralogical composition and vary mostly in their microfossils and opaque ferrous mineral content. The composition of the clay points to an origin from weathered marlstone, probably Miocene, that is present in an area less than $10 \mathrm{~km}$ north and south from Krašnja, but is not present in the Črni graben valley. The local clays have a different mineralogical composition, without microfossil remains, as we proved with the analysis of the remains of a contemporaneous kiln excavated in situ.

Krašnja also had two of the very rare pottery kilns dating to this period in Slovenia. They are oval in shape and probably used for firing pottery. The maximum temperature inside the kiln was only around $800^{\circ} \mathrm{C}$, as proved by the analysis of pottery from Krašnja; the kiln walls were fired at even lower temperatures (see above).

All the fabrics contained added crushed calcite grains that could also have been gathered in the valley north and south of Krašnja. The potters rarely added crushed old pottery or grog along with calcite to the fabrics. The vessels were then shaped, dried, and fired in an open fire in a mostly incomplete oxidising atmosphere. 


\section{References}

Arnold D. E. 1985. Ceramic theory and cultural process. Cabridge University Press. Cambridge.

Bregant T. 1974a. Kolišče ob Maharskem prekopu pri Igu - raziskovanja leta 1970. Poročilo o raziskovanju neolita in eneolita Slovenije 3: 7-34.

1974b. Kolišče ob Maharskem prekopu pri Igu - raziskovanja leta 1972. Poročilo o raziskovanju neolita in eneolita Slovenije 3: 39-66.

1975. Kolišče ob Maharskem prekopu pri Igu - raziskovanja 1973. in 1974. leta. Poročilo o raziskovanju neolita in eneolita Slovenije 4: 7-106.

Cultrone G., Rodriguez-Navarro C., Sebastian E., Cazalla O. and De La Torre M. J. 2001. Carbonate and silicate phase reactions during ceramic firing. European Journal of $\mathrm{Mi}$ neralogy 13(3): 621-634.

Grimshaw R. W. 1971. The Chemistry and Physics of Clays and Allied Ceramic Materials. Ernest Benn Ltd. London.

Harrison S. 2008. An experimental prehistoric pottery firing at Harray, Orkney. Antiquity 82(317): Project gallery. http://www.antiquity.ac.uk/projgall/harrison/

Horvat A., Mišič M. 2004. Mineralogy and sedimentology of diatomaceous sediments from Slovenia. RMZ - Materials and Geoenvironment 51(4): 2145-2161.

Horvat M. 1999. Keramika: tehnologija keramike, tipologija lončenine, keramični arhiv. Znanstveni inštitut Filozofske fakultete. Ljubljana.

Horvat M., Masaryk R., Klasinc R., Soklič J., Verbič T. and Štuhec S. 2014a. Arheološke raziskave v Krašnji v letu 2013. Zbornik Občine Lukovica II: 66-71.

Horvat M., Masaryk R., Klasinc R., Verbič T., Soklič J., Štuhec S., Žibrat Gašparič A., Mirtič B., Sraka M. and Culiberg M. 2014b. Končno poročilo o arheoloških raziskavah na lokaciji Krašnja. Unpublished excavation report by the Archaeologic consortium (Faculty of Arts, University of Ljubljana; Institute of Archaeology, Slovene Academy of Sciences and Arts; Arhej d.o.o.). Ljubljana.

Kramar S. 2013. Mineraloško-petrografska in kemična sestava lončenine in gline iz lončarskih peči. In M. Horvat et al., Cogetinci pri Lenartu. Zbirka Arheologija na avtocestah Slovenije 37. Zavod za varstvo kulturne dediščine Slovenije. Ljubljana: 225-231.

Mlekuž D., Žibrat Gašparič A., Horvat M. and Budja M. 2012. Houses, pots and food: the pottery from Maharski prekop in context. Documenta Praehistorica 39: 325338.

Osterc V. 1975. Mineralna sestava in mikrostruktura keramike s kolišča ob Maharskem prekopu I. Poročila o raziskovanju neolita in eneolita v Sloveniji 4: 123-134.

Premru U. 1983. Tolmač za list Ljubljana: L 33-66: Socialistična federativna republika Jugoslavija, osnovna geološka karta, 1:100 000. Zvezni geološki zavod. Beograd.

Quinn P. S. 2008. The Occurrence and Research Potential of Microfossils in Inorganic Archaeological Materials. Geoarchaeology: An International Journal 23(2): 275-291.

Quinn P., Burton M. 2009. Ceramic petrography and the reconstruction of hunter-gatherer craft technology in Late Prehistoric southern California. In P. S. Quinn (ed.), Interpreting silent artefacts. Petrographic Approaches to Archaeological Ceramics. Archaeopress. Oxford: 267-295.

Reedy C. L. 2008. Thin-Section Petrography of Stone and Ceramic Cultural Material. Archetype Publications. London.

Rice P. M. 1987. Pottery Analysis. A Sourcebook. The University of Chicago Press. Chicago and London.

Rokavec D. 2014. Gline v Sloveniji / Clays in Slovenia. Geološki zavod Slovenije. Ljubljana.

Rye O. S. 1981. Pottery Technology. Principles and Reconstruction. Manuals on Archaeology 4. Taraxacum. Washington.

Sillar B., Tite M. S. 2000. The challenge of 'technological choices' for materials science approaches in archaeology. Archaeometry 42(1): 2-20.

Stražar S. 1985. Črni graben, od Prevoj do Trojan. Kulturno-umetniško društvo Janko Kersnik Lukovica. Lukovica.

Terry R., Chilingar G. 1955. Summary of 'Concerning some additional aids in studying sedimentary formations' by $\mathrm{M}$. S. Shvetsov. Journal of Sedimentary Research 25: 229234.

Tite M. S., Kilikoglou V. and Vekinis G. 2001. Strength, toughness and thermal shock resistance of ancient ceramics, and their influence on technological choice. Archaeometry 43(3): 301-324.

Urankar R. 2012. Arheometrične raziskave kovinskih izdelkov in polizdelkov iz bronaste dobe ter rude na 
Slovenskem. Unpulished PhD thesis. Faculty of Arts. University of Ljubljana. Ljubljana.

Velušček A. (ed.) 2004. Hočevarica: eneolitsko kolišče na Ljubljanskem barju / Hočevarica: an Eneolithic piledwelling in the Ljubljansko barje. Opera Instituti Archaeologici Sloveniae 9. Institute of Archaeology ZRC SAZU. Založba ZRC. Ljubljana.

(ed.) 2009. Koliščarska naselbina Stare gmajne in njen čas / Stare gmajne pile-dwelling and its era. Opera Instituti Archaeologici Sloveniae 16. Institute of Archaeology ZRC SAZU. Založba ZRC. Ljubljana.

Whitbread I. K. 1986. The characterisation of argillaceous inclusions in ceramic thin sections. Archaeometry 28(1): 79-88.
1995. Greek Transport Amphorae. A Petrological and Archaeological Study. Fitch Laboratory Occasional Paper 4. The British School at Athens. Exeter.

Žibrat Gašparič A. 2008. Strukturna analiza neolitske keramike in lončarske tehnologije. Unpublished $\mathrm{PhD}$ thesis. Faculty of Arts. University of Ljubljana. Ljubljana.

2013. A new look at old material: ceramic petrography and Neo/Eneolithic pottery traditions in the eastern Ljubljansko barje, Slovenia. Documenta Praehistorica 40: $147-164$ 